Physi cal and chemical properti es of concrete usi ng GGBFS- KR sl ag- gypsum bi nder

\begin{tabular}{|l|l|}
\hline 著者 & CHO Bongsuk, CHO Hyeonggi I \\
\hline $\begin{array}{l}\text { j our nal or } \\
\text { publ i cat i on t i t I e }\end{array}$ & Const ruct i on and Bui I di ng Nat er i al s \\
\hline vol une & 123 \\
\hline page range & $436-443$ \\
\hline year & $2016-10-01$ \\
\hline URL & ht t p: //hdl . handl e. net /10258/00009204 \\
\hline
\end{tabular}




\title{
Physical and chemical properties of Concrete using GGBFS-KR slag-Gypsum Binder
}

\author{
Bongsuk Cho ${ }^{1)}, \quad$ Hyeonggil CHOI $^{2)}$
}

${ }^{1)}$ Senior Researcher, Slag Utilization Research Team,

Research Institute of Industrial Science \& Technology, Pohang, South Korea

${ }^{2)}$ Professor, Graduate School of Engineering, Muroran Institute of Technology, Hokkaido, Japan

\section{Corresponding author}

E-mail : chg810@mmm.muroran-it.ac.jp

Tel. : +81-143-46-5214

C.P : $+81-80-3590-5900$ 


\begin{abstract}
The Kambara reactor (KR) slag, which is a byproduct generated in the preliminary treatment process of molten iron by a $\mathrm{KR}$ mechanical stirring process, is composed of $\mathrm{Ca}(\mathrm{OH})_{2}, \mathrm{CaCO}_{3}$ and $2 \mathrm{CaO} \cdot \mathrm{SiO}_{2}$. It was confirmed that the alkali stimulus of $\mathrm{Ca}(\mathrm{OH})_{2}$ contained in the $\mathrm{KR}$ slag could cause a cement-free binder to harden. However, the strength performance of a GGBFS-based cement-free binder mixed with only the KR slag was very low. The gypsum $\left(\mathrm{CaSO}_{4}\right)$ is additionally used in order to enhance the strength performance of the GGBFS-KR slag binder. The result showed that the 28-day compressive strength of the GGBFS-KR slaggypsum binder (GKGB) concrete was similar to that of slag cement. On the other hand, compared to those of slag cement, the drying shrinkage was shown to be $121.8 \% \sim 129.0 \%$, and the cumulate porosity was shown to be $190 \%$ 208\%. These results imply that ettringite, which is a main hydrate of GKGB, is thick and provides the structural stability by forming a frame structure. However, the thicker ettringite, the more pores may be created. In other words, high amounts of ettringite form a porous structure, which has many micro pores so that the porosity and absorption become higher, leading to higher drying shrinkage.
\end{abstract}

\title{
Keywords
}

Cement-free binder, GGBFS, KR slag, Gypsum, Iron \& steel making process, Ettringite, Shrinkage, Strength, Porosity

\section{Introduction}

About $900 \mathrm{~kg}$ of $\mathrm{CO}_{2}$ is generated and about $1,510 \mathrm{kWh}$ is consumed to manufacture one ton of the OPC (Ordinary Portland Cement) [1]. On a unit weight basis, the enormous volume of cement produced is responsible for approximately $5 \%$ of the global anthropogenic $\mathrm{CO}_{2}$ production [2,3].

As an environmental sustainability becomes a greater priority, solutions are being sought to reduce $\mathrm{CO}_{2}$ and an energy burden of the cement without sacrificing an economic viability. These include emission sequestration, concretes with lower OPC content, blends of OPC with additives like as fly-ash, blast furnace slag, lime stone powder, and more [4,5]. In particular, a cement-free binder using the alkali activator such as sodium, potassium (alkali-activated cement) has been actively studied. Purdond et al. reported that $\mathrm{NaOH}$ can be used as a hydration reaction activator and that the strength of the concrete can be improved by increasing the concentration of the activator. Additionally, the authors observed that within a certain range, the strength of GGBFS concrete is independent of the concentration of $\mathrm{NaOH}$, and if the concentration of the activator is excessive, the strength reduces [6,7]. On the other hand, Jolicoeur et al. showed that when the $\mathrm{NaOH}$ concentration is more than 5\% in a binder mixture, the concrete strength decreases [8]. Li et al. reported that the combination of $\mathrm{NaOH}$ and $\mathrm{Na}_{2} \mathrm{CO}_{3}$ is more effective than $\mathrm{NaOH}$ or $\mathrm{Na}_{2} \mathrm{CO}_{3}$ alone, in terms of the strength of the activated cement mortar [9]. Fernandez-Jimenez et al. investigated the effect of the composition of water glass, $\mathrm{NaOH}$, and $\mathrm{Na}_{2} \mathrm{CO}_{3}$ on the strength of the obtained alkali-activated slag cements. They found that silicate salt anions increase the strength of slag cements whereas carbonate anions reduce it [10].

These sodium-based activators help high strength develop effectively by contributing to the generation of high concentration of $\mathrm{OH}^{-}[11,12,13]$. However, the sodium- based activators have disadvantages, such as decreased 
workability due to a quick setting, a high cost, a high toxicity with pH14 or higher, and an expansion characteristic from reactions of alkali-silica and reactive aggregate [14,15,16].

For these reasons, the author of this research has been focused on finding a new alkali-activator based on Calcium-type. The Calcium-based alkali activator is believed to resolve the aforementioned problems that sodium-type activators have. In particular, from the perspective of an effective utilization of industrial byproducts we paid attention to industrial byproducts [17]. As a result, we found a Kambara Reactor (KR) slag, which is a byproduct generated in the steel making process. The KR slag is generated in the preliminary treatment process of molten iron. In general, if even a scant amount of sulfur is mixed in molten steels, the quality of the final products will be deteriorated. Therefore, the molten iron manufactured in a blast furnace is processed through a desulfurization process in order to eliminate sulfur, containing 1\% 3\% of the total mass. Kambara Reactor stirring is the representative desulfurization process. In the KR process, a mechanical stirring is performed after a desulfurization addictive such as $\mathrm{CaO}$ is supplied. Then, the sulfur in the molten iron is reacted with $\mathrm{CaO}$, and turned into a chemical compound with $\mathrm{CaS}$. The $\mathrm{CaS}$ compound and unreacted $\mathrm{CaO}$ rises to the surface of the molten iron due to its low specific gravity and turns into a slag, which is called the KR slag. The KR slag filled in a moving pot is transferred to the cooling yard. Next, water is sprayed to control scattering dust and achieve rapid cooling. After the water spraying, iron is recovered from the slag through the process of crushing and magnetic separation. The recovered iron is recycled as a substitute for iron ore or scrap in the iron \& steel making process. The non-magnetic KR slag, the final remnant in the process, consists of sand-shaped grains with diameter of $2 \mathrm{~mm}$ or less. It is used only for road-base or landfill with a mixture of a convert slag. Korean steel makers generate up to about 400,000 ton/year of the non-magnetic KR slag, but it has not yet been utilized except as materials for civil works.

The KR slag is containing abundant $\mathrm{CaO}$, and is cooled through water spraying, and a considerable amount of $\mathrm{CaO}$ turns into $\mathrm{Ca}(\mathrm{OH})_{2}$. On the other hand, one of the representative byproducts containing abundant calcium is the amorphous blast furnace slag. The surface of ground granulated blast furnace slag (GGBFS) is coated with a glass state film, and has low reactivity. However, if it is exposed to a high-pH environment, the glass state film is destroyed, and $\mathrm{Ca}^{2+}, \mathrm{Si}^{4+}$, and $\mathrm{Al}^{3+}$ are eluted from within GGBFS, and then hydrates such as C-S-H (xCaO$\mathrm{ySiO}_{2}-\mathrm{zH}_{2} \mathrm{O}$, calcium silicate hydrates), C-A-H (xCaO-y $\mathrm{Al}_{2} \mathrm{O}_{3}-\mathrm{zH}_{2} \mathrm{O}$, calcium aluminum hydrates) are formed. The $\mathrm{OH}^{-}$is needed to form a high $\mathrm{pH}$ environment. The $\mathrm{OH}^{-}$serves as a trigger for chemically stable GGBFS to be reactive. The $\mathrm{KR}$ slag contains $\mathrm{Ca}(\mathrm{OH})_{2}$, and it can generates $\mathrm{OH}^{-}$ions upon its reaction with water, and hardens the GGBFS-based binder [18,19,20].

Through the previous study, it was confirmed that the alkali stimulus of $\mathrm{Ca}(\mathrm{OH})_{2}$ contained in the $\mathrm{KR}$ slag could cause the cement-free binder to harden. However, the compressive strength of the GGBFS-KR slag binder mixed with only the KR slag was compared with that of OPC.

In general, ettringite in the initial hydration period can fill the gaps of hydrates such as $\mathrm{C}-\mathrm{S}-\mathrm{H}$ and $\mathrm{C}-\mathrm{A}-\mathrm{H}$, and as a result, the density and strength are improved. $\mathrm{CaSO}_{4}$ should be provided in order to get more ettringite. On this background, $\mathrm{CaSO}_{4}(\mathrm{AG}$; Anhydrous gypsum) is additionally used in order to improve the strength performance of the cement-free binder made of GGBFS and the KR slag (GKGB ; GGBFS-KR slag-gypsum binder). In this study, tests of the compressive strength and drying shrinkage of the GKGB concrete manufactured utilizing the KR slag and gypsum were performed in order to investigate engineering properties. 
In addition, the heat evolution, X-ray diffraction (XRD), thermogravimetry / differential thermal analysis (TG/DTA), mercury intrusion porosimetry (MIP), and scanning electron microscopy (SEM) for paste specimens were reviewed in order to analyze hydration characteristics.

\section{Experimental plans}

\subsection{Test Materials}

The materials used were shown in Table 1. The KR slag is produced as a byproduct in the iron-producing process. In the cooling process, since water is sprayed, $\mathrm{CaO}$ included in the $\mathrm{KR}$ slag turned into $\mathrm{Ca}(\mathrm{OH})_{2}$. The $\mathrm{KR}$ slag contains much $\mathrm{CaO}$, and other components such as $\mathrm{SiO}_{2}, \mathrm{Fe}_{2} \mathrm{O}_{3}$ and $\mathrm{SO} . \mathrm{CaO}$ existed in the form of a compound including $\mathrm{Ca}(\mathrm{OH})_{2}, 2 \mathrm{CaO} \cdot \mathrm{SiO}_{2}$. According to the TG-DTA measurement value, the amount of $\mathrm{Ca}(\mathrm{OH})_{2}$ in KR slag was approximately $25 \%$. Thus, it can be determined that the amount of $\mathrm{CaO}$ tunes into $\mathrm{Ca}(\mathrm{OH})_{2}$ due to cooling is approximately $19 \%$. And, remaining $\mathrm{CaO}$ in $\mathrm{KR}$ slag is present in a compound of $\mathrm{CaO}-\mathrm{SiO}_{2}$ and Free-CaO. As shown in Table 2, the KR slag has a significantly lower portion of $\mathrm{SiO}_{2}$ and $\mathrm{Al}_{2} \mathrm{O}_{3}$ than GGBFS, while the KR slag contains more $\mathrm{CaO}, \mathrm{Fe}_{2} \mathrm{O}_{3}$ than GGBFS. The $\mathrm{KR}$ slag is generated from the desulfurization addictive $(\mathrm{CaO})$, which was applied to remove the meager amount of sulfur in molten iron so that it has a high $\mathrm{CaO}$ content. In addition, approximately $30 \%$ to $40 \%$ of $\mathrm{Fe}$ component is in the KR slag before the magnetic selection. The Fe component is recovered through drying, crushing and magnetic selection, and reused in the steel making process. The total Fe content of Fe-rich slags collected by a magnetic separation is $50 \%$ to $70 \%$, which is used for the steel making process as raw materials. $\mathrm{The}_{\mathrm{Fe}} \mathrm{O}_{3}$ content in the non-magnetic $\mathrm{KR}$ slag is approximately $10 \%$, which is not enough to recycle. Unburned cokes, which are deoxidizers, also exist in molten iron and most of the unburned cokes are mixed with the slag. KR slag thus contains about $4-5 \%$ coke (a carbon component). The most effective property of the non-magnetic $\mathrm{KR}$ slag is its high $\mathrm{CaO}$ content, and it is highly likely to be utilized as a cement-based material. As mentioned above, the KR slag is the non-magnetic slag collected through repeated processes of drying, crushing, and magnetic separation. The Blaine fineness of the KR slag powder was about $4,040 \mathrm{~cm}^{2} / \mathrm{g}$. The Blaine fineness of GGBFS, anhydrous gypsum, OPC used was $4,330 \mathrm{~cm}^{2} / \mathrm{g}, 4,530 \mathrm{~cm}^{2} / \mathrm{g}, 3,410 \mathrm{~cm}^{2} / \mathrm{g}$, respectively.

The coarse aggregate used to make the concrete specimen was crushed gravel with maximum size of $25 \mathrm{~mm}$, absorption of $1.28 \%$, and specific gravity of $2.65 \mathrm{~g} / \mathrm{cm}^{3}$. And, the fine sand was river sand with absorption of $1.03 \%$ and specific gravity of $2.54 \mathrm{~g} / \mathrm{cm}^{3}$.

\subsection{Mixture proportions of concrete}

The concrete mix proportion for the evaluation of compressive strength and drying shrinkage is indicated in Table 3. The setting valves of water to binder ratio, the unit weight of binder and water were $48.5 \%, 340 \mathrm{~kg} / \mathrm{m}^{3}$ and $165 \mathrm{~kg} / \mathrm{m}^{3}$, respectively. The GKGB concretes were set as 3 types: GGBFS81+KR10+AG9, GGBFS78+KR10+AG12, GGBFS75+KR10+AG15. At this time, OPC 100 and OPC50+GGBFS50 were made as comparison specimens, and the polycarboxylate-based superplasticizer was mixed at $0.9 \%$ of binder weight. The specified concrete strength was $24 \mathrm{MPa}$. The target slump and air content were set at $180 \pm 25 \mathrm{~mm}, 4.5 \pm 1.5 \%$, 
respectively [21]. The paste specimen for analyses of heat evolution, XRD, porosity, TG-DTA, and SEM was manufactured with water/binder ratio of 0.5 .

\subsection{Test methods}

The compressive strength test of concrete was performed based on ASTM C39/C39M by preparing a specimen with a size of $\varphi 100 \times 200 \mathrm{~mm}$. After water curing at $20 \pm 3^{\circ} \mathrm{C}$, the compressive strength was measured after $1,3,7$, 14, 28 and 91 days. The concrete specimen for the drying shrinkage test was cured in the water for 7 days, after being detached from the mold. Then, the changes in length were measured under conditions of $20^{\circ} \mathrm{C}$ and $60 \%$ humidity for 130 days [22]. In addition, the analyses of heat evolution, XRD, TG/DTA, porosity, SEM were performed in order to investigate hydration properties on the GKGB. The hydration heat was measured at 30second intervals using the calorimeter (MMC-511SV6, Tokyo Rico Corp.) for 7 days. Before test, the binder was placed in the container 2 days ago, and the temperature was kept at $20^{\circ} \mathrm{C}$. The TG-DTA (Seiko Instrument Crop. EXTRA 6000) analysis of the paste specimen was implemented at the age of 91 days. The temperature in the instrument was raised from $20^{\circ} \mathrm{C}$ up to $1100^{\circ} \mathrm{C}$ under the atmospheric condition. The XRD (Rigaku Corp. D/Max-2500V) analysis for paste specimens at the age of 3, 7 and 28 days were performed in order to investigate hydration products. In addition, the shape and the distribution of hydration products were observed through SEM (HITACHI Corp. S-4300SE).

The micro pore distribution for paste specimens at the age of 91 days was also investigated through the MIP test (ASTM D 4284). MIP has been one of the most widely used methods to analyze the pore structure of cement materials; it involves checking the volume of mercury that is inserted in the sample [23]. By using the simple principle of MIP, the pore size and distribution can be calculated. The equation used for the calculation is the Washburn equation (equation (1)), which defines the shape of a pore as a cylindrical capillary. The size of the pores that are intruded is inversely proportional to the applied pressure [24].

In addition, the absorption of the paste specimen was measured using the equation (2) below.

Absorption $(\%)=[($ saturated surface dry weight - absolute dry weight $) /$ absolute dry weight $] \times 100$

\section{Results and discussion}

\subsection{Properties of GKGB concrete}

\subsubsection{Slump and air content of fresh concrete}

As shown in Table 4, the slump and air content of the GKGB concrete was within the target range of $180 \pm 25 \mathrm{~mm}$ and $4.0 \pm 1.0 \%$, respectively. It was found that the slump and air content of the GKGB concrete was similar to that of OPC100\% and OPC50+GGBFS50 concrete. It indicates that there is no difference in fresh properties between the ordinary concrete and the GKGB concrete.

\subsubsection{Compressive strength}


Through the previous study, it was confirmed that the compressive strength of the GGBFS-KR slag binder mixed with only the KR slag was much lower compared with that of OPC. The method of mixing anhydrous gypsum additionally was suggested to increase the compressive strength of GGBFS-KR slag binder.

The main component of gypsum is $\mathrm{CaSO}_{4}$, and it is dissolved into $\mathrm{Ca}^{2+}$ and $\mathrm{SO}_{4}{ }^{2-}$ ions in the reaction with water. In addition, $\mathrm{Ca}^{2+}$ contributes to the formation of hydration products. More than anything else, $\mathrm{CaSO}_{4}$ can also make a contribution to the generation of ettringite. Ettringite is needle-shaped hydrates, and fills the gaps between the hydration products, resulting in compaction of the specimen as well as improved strength. Fig. 1 shows the compressive strength of the GKGB concrete. In addition, Fig. 2 illustrates the compressive strength development rate of the GKGB concrete under the hypothesis that the compressive strength of the OPC concrete was set at $100 \%$. The black dotted bold line shows the compressive strength of OPC.

The mixing proportion of the KR slag was set at $10 \%$, which was considered not to cause any decrease in workability, and the mixing proportion of anhydrous gypsum was set at $9 \%, 12 \%$ and $15 \%$.

The 1-day, 3-day compressive strength of the GKGB concrete was very low compared with that of OPC and OPC50+GGBFS50; however, the gap was greatly decreased with the elapse of 7 days. In particular, it is found that the 28-day compressive strength of the GKGB (GGBFS75+KR10+AG15) concrete can be similar with that of OPC50+GGBFS50 (slag cement). The compressive strength at 28 days of OPC, OPC50+GGBFS50, GGBFS75+KR10+AG15, GGBFS78+KR10+AG12 and GGBFS81+KR10+AG9 were measured at 44.8 MPa, 43.3 $\mathrm{MPa}$, 41.4 MPa, 37.9 MPa, and 32.5 $\mathrm{MPa}$, respectively.

The 28-day compressive strength of GGBFS75+KR10+AG15 was measured at $41.4 \mathrm{~N} / \mathrm{mm}^{2}$, which is $92.4 \%$ of the $44.8 \mathrm{~N} / \mathrm{mm}^{2}$ measured in OPC. In addition, the 91-day compressive strength of GGBFS75+KR10+AG15 was shown to be $95.5 \%$ compared with that of OPC. However, the 28-day and 91-day compressive strengths of GGBFS81+KR10+AG9 were shown to be $72.5 \%\left(32.5 \mathrm{~N} / \mathrm{mm}^{2}\right)$ and $77.9 \%\left(38.1 \mathrm{~N} / \mathrm{mm}^{2}\right)$, respectively, compared with those of OPC, which was significantly lower.

\subsubsection{Drying shrinkage}

Fig. 3 indicates the evaluation results of the drying shrinkage of the GKGB concrete up to 130days. The drying shrinkage value was in the order of GKGB > OPC50+GGBFS50 > OPC. The drying shrinkage of the OPC50+GGBFS50 concrete was higher than that of OPC. This may be because the relatively higher Blaine fineness of GGBFS brought about greater capillary tension (GGBFS: $4,330 \mathrm{~cm}^{2} / \mathrm{g}$, OPC: $3,410 \mathrm{~cm}^{2} / \mathrm{g}$ ). Overall, large changes of the drying shrinkage values after 70days were not found.

Compared with OPC and OPC50+GGBFS50, it was found that the GKGB concrete had much higher drying shrinkage. The drying shrinkage at 130 days of OPC, OPC50+GGBFS50, GGBFS75+KR10+AG15, GGBFS78+KR10+AG12 and GGBFS81+KR10+AG9 was -474um, -545um, -703um, -664 um, and -686um, respectively.

When the drying shrinkage value of OPC50\%+GGBFS50 was hypothesized as 100\%, GGBFS75+KR10+AG15, GGBFS78+KR10+AG12 and GGBFS81+KR10+AG9 was 129\%, 121.8\%, and 125.9\%, respectively. In addition, Compared with OPC, the drying shrinkage of the GKGB concrete was evaluated to be $144.7 \%$ to $148.3 \%$ (GGBFS75+KR10+AG15: 148.3\%, GGBFS78+KR10+AG12: 140.1\%, GGBFS81+KR10+AG9: 144.7\%) 
As described above, the drying shrinkages value of GKGB were much higher than that of OPC and OPC50+GGBFS50. However, differences of the drying shrinkage value with the types of GKGB were not significant. In condition mixed with $10 \%$ of KR slag, significant differences of the drying shrinkage with the amount of gypsum (9\% 15\%) were not found. As mentioned above, the compressive strength of the GKGB concrete was found to be similar with that of OPC50+GGBFS50. However, the drying shrinkage of the GKGB concrete was very high compared with that of the OPC50+GGBFS50. The drying shrinkage of concrete is closely related with cracks and deterioration in durability. The causes of high drying shrinkage and a method of reducing the drying shrinkage of the GKGB concrete should be sought.

\subsection{Analysis of hydration characteristics}

\subsubsection{Hydration heat}

Fig. 4(a) shows the results of an evaluation of hydration heat of OPC, OPC50+GGBFS50 and GKGB. The first heat peak is the exothermic reaction resulting from the reaction of water with $\mathrm{CaO}$ or $3 \mathrm{CaO} \cdot \mathrm{Al}_{2} \mathrm{O}_{3}$. The second heat peak was the heat of reaction in the generation process of C-S-H gel in the reaction of $3 \mathrm{CaO} \cdot \mathrm{SiO}_{2}$, $2 \mathrm{CaO} \cdot \mathrm{SiO}_{2}$ with water. These hydration heat peaks appeared between $13 \mathrm{hr}$ and $14 \mathrm{hr}$ in OPC, and between 18 $\mathrm{hr}$ and $19 \mathrm{hr}$ in OPC50+GGBFS50. On the other hand, the peak appeared between $26 \mathrm{hr}$ and $30 \mathrm{hr}$ in GKGB, which shows significantly delayed hydration. Above all things, the level of the hydration heat peak was very low in GKGB compared with OPC and OPC50+GGBFS50.

The cumulative heat release with binder types for 7 days is presented in Fig. 4(b). The cumulative heat releases of OPC, OPC50+GGBFS50, GGBFS75+KR10+AG15, GGBFS78+KR10+AG12, and GGBFS81+KR10+AG9 were 301.4J/g (100\%), 211.7J/g (70.2\%), 109.4J/g (36.3\%), 97.9J/g (32.5\%), and 82.3J/g (27.3\%), respectively. In addition, while it is a minor factor, the more gypsum was mixed into GKGB, the higher the cumulative heat release was evaluated. From the facts described above, it is confirmed that GKGB has properties of very low hydration heat, and it is believed to be useful to reduce hydration heat in manufacturing mass concrete.

\subsubsection{XRD and TG/DTA}

Fig. 5 presents XRD of OPC, OPC50+GGBFS50 and GGBFS75+KR10+AG15 paste at 91 days. The main hydrates found in OPC and OPC50+GGBFS50 paste were $\mathrm{Ca}(\mathrm{OH})_{2}, \mathrm{C}-\mathrm{S}-\mathrm{H}, \mathrm{C}-\mathrm{A}-\mathrm{H}, 2 \mathrm{CaO} \cdot \mathrm{SiO}_{2}$ and $3 \mathrm{CaO} \cdot \mathrm{SiO}_{2}$. In OPC50+GGBFS50, the $\mathrm{Ca}(\mathrm{OH})_{2}$ peaks appearing around ${ }^{\circ} 18,{ }^{\circ} 34,{ }^{\circ} 47,{ }^{\circ} 51$ and ${ }^{\circ} 54$ were lower than that of OPC. This may be because the amount of $\mathrm{Ca}(\mathrm{OH})_{2}$ generated from $\mathrm{OPC}$ was decreasing in the pozzolanic reaction with GGBFS. On the other hand, the hydration products of GKGB are considerably different from those of OPC and OPC50+GGBFS50, in that the main hydrates are ettringite. When the KR slag and gypsum are added in GGBFS, the following reaction could occur:

$\left[\mathrm{GGBFS}+\mathrm{Ca}(\mathrm{OH})_{2}+\mathrm{CaSO}_{4} \rightarrow 3 \mathrm{CaO} \cdot \mathrm{Al}_{2} \mathrm{O}_{3} \cdot 6 \mathrm{H}_{2} \mathrm{O}+3 \mathrm{CaSO}_{4}+26 \mathrm{H}_{2} \mathrm{O} \rightarrow 3 \mathrm{CaO} \cdot \mathrm{Al}_{2} \mathrm{O}_{3} \cdot 3 \mathrm{CaSO}_{4} \cdot 32 \mathrm{H}_{2} \mathrm{O}\right]$ In other words, $\mathrm{Ca}^{2+}, \mathrm{Al}^{3+}$ eluted from GGBFS by the alkaline stimuli of hydroxide ions of the $\mathrm{KR} \operatorname{slag}\left(\mathrm{Ca}(\mathrm{OH})_{2}\right)$ lead to form C-A-H hydrates $\left(3 \mathrm{CaO} \cdot \mathrm{Al}_{2} \mathrm{O}_{3} \cdot 6 \mathrm{H}_{2} \mathrm{O}\right)$. Then, ettringite hydrates are formed by reaction of C-A-H hydrates and gypsum $\left(\mathrm{CaSO}_{4}\right)$. 
Fig. 6 shows the TG/DTA evaluation results of OPC, OPC50+GGBFS50 and GGBFS75+KR10+AG15 paste at the age of 91 days. OPC was observed to decrease in weight between $450^{\circ} \mathrm{C}$ and $500^{\circ} \mathrm{C}$. This may be due to the thermal degradation of the hydration product of $\mathrm{Ca}(\mathrm{OH})_{2}$ generated from OPC. In terms of the weight loss rate caused by the thermal degradation of $\mathrm{Ca}(\mathrm{OH})_{2}$, OPC50+GGBFS50 was shown to be comparatively low compared with OPC. This may be because the amount of $\mathrm{Ca}(\mathrm{OH})_{2}$ generated from OPC was decreasing in the pozzolanic reaction with GGBFS. On the other hand, and GKGB was shown to have an explicitly different weight loss pattern according to the thermal increase from OPC and OPC50+GGBFS50. Almost no weight loss was found in the temperature range between $450^{\circ} \mathrm{C}$ and $500^{\circ} \mathrm{C}$.

The slope of the weight loss curve of GKGB was steeper around the temperature of $120^{\circ} \mathrm{C}$ compared with that of OPC and OPC50+GGBFS50. This may be because ettringite lost water of crystallization in the endothermic reaction. In addition, the weight was slightly increasing in the temperature range between $850^{\circ} \mathrm{C}$ and $1000^{\circ} \mathrm{C}$. This may be because a small amount of Fe contained in the KR slag was oxidized at a high temperature in the reaction with oxygen.

\subsubsection{Porosity and absorption}

Fig. 7(a) is the cumulative porosity of OPC, OPC50+GGBFS50 and GKGB measured using MIP. The specimens for measuring MIP were paste at the age of 91days. In terms of the cumulative porosity, GKGB was comparatively higher than OPC and OPC50+GGBFS50. The cumulative volume of mercury intruded at each of OPC, OPC50+GGBFS50, GGBFS81+KR10+AG9, GGBFS78+KR10+AG12, and GGBFS75+KR10+AG15 was $0.064 \mathrm{ml} / \mathrm{g}, 0.081 \mathrm{ml} / \mathrm{g}, 0.154 \mathrm{ml} / \mathrm{g}, 0.160 \mathrm{ml} / \mathrm{g}$, and $0.167 \mathrm{ml} / \mathrm{g}$, respectively. The cumulative porosity of GKGB was evaluated over twice higher to be $239 \sim 261 \%$ compared with that of OPC. In three different types of GKGB, it was found that the higher the gypsum content, the slightly greater the cumulative porosity. The pore distribution characteristics in each specimen are presented in Fig. 7(b), Fig. 7(c) and Table 5. In terms of pore size, the capillary porosity in a range of $10 \sim 100 \mathrm{~nm}$ had the highest portion of all the pores. In terms of gel pores with diameter of $10 \mathrm{~nm}$ or less, there was almost no difference in porosity by binder type. Of course, GKGB was slightly greater than OPC and OPC50+GGBFS50, but it is considered that there are no significant differences. On the other hand, in terms of $10 \sim 100 \mathrm{~nm}$ - and $100 \sim 10000 \mathrm{~nm}$-sized pores, GKGB has a considerably large quantity of pores compared with OPC and OPC50+GGBFS50. In particular, when the capillary porosity of OPC was set as 100\%, $10 \sim 100 \mathrm{~nm}$-sized capillary porosity of OPC50+GGBFS50, GGBFS75+KR10+AG15, GGBFS78+KR10+AG12, and GGBFSS81\%+KR10\%+AG9\% were 133.4\%, 191.1\%, $207.6 \%$, and $167.9 \%$, respectively. The capillary porosity in a range of $10 \sim 100 \mathrm{~nm}$ had the highest proportion of all pores, GKGB is about 1.6 to 2.0 times higher than OPC.

In addition, Fig. 8 shows the evaluation of the absorption of the paste specimens at 91 days. An absorption is closely related with a porosity. The absorption of OPC, OPC50+GGBFS50, GGBFS75+KR10+AG15, GGBFS78+KR10+AG12, and GGBFS81+KR10+AG9 was evaluated as 6.2\%, 7.9\%, 13.4\%, 13.1\%, and 12.8\%, respectively. Overall, porosity and absorption of GKGB were very high compared with those of OPC and OPC50+GGBFS50.

As seen above, the most significant difference between GKGB, OPC and OPC50+GGBFS50 lies in the main hydrates. The main hydrates of OPC and OPC50+GGBFS50 were $\mathrm{Ca}(\mathrm{OH})_{2}, \mathrm{C}-\mathrm{S}-\mathrm{H}$ and $\mathrm{C}-\mathrm{A}-\mathrm{H}$, while the main 
hydrates of GKGB are ettringite. The difference in hydrate types can be a key factor that may determine the micro pore structure. Ettringite, the main hydrates of GKGB, which may be present as the porous structure which forms a large quantity of pores.

\subsubsection{SEM image}

Fig. 9 shows the SEM image of OPC and GKGB (GGBFS75+KR10+AG15) paste specimens. In general, ettringite is needle-shaped. Compared with the thin needle-shaped ettringite in OPC, ettringite in GKGB has a rather thick needle-shape as shown in Fig. 9(a) and 9(b). If there is much ettringite with a comparatively thick needle shape, it forms a sort of a frame structure and contributes to the structural stability, resulting in high strength of hardened cement. It is the reason that the compressive strength similar to slag cement can be developed using GKGB. However, it is difficult to make the pores dense even with a large quantity of ettringite when there is a small amount of CaO-based hydrates (C-S-H, C-A-H). Moreover, the thicker ettringite, the more pores may be created as shown in Fig.9(c) and 9(d).

As mentioned previously, GKGB had a high drying shrinkage and a high absorption as well as a high compressive strength. These results imply that ettringite, which is a main hydrate of GKGB, is thick and provides the structural stability by forming a frame structure. However, the thicker ettringite, the more pores may be created. In other words, high amounts of ettringite form a porous structure, which has many micro pores so that the porosity and absorption become higher, leading to higher drying shrinkage.

\section{Conclusions}

The compressive strength, drying shrinkage, heat evolution, and analyses of XRD, TG/DTA, MIP, and SEM were performed in order to investigate engineering properties and hydration characteristics of the GKGB concrete. The findings of this research can be categorized as follows:

1. It was found that the alkali stimulus of the KR slag could cause the cement-free binder based on GGBFS to harden, but the 28-day compressive strength of the GGBFS-KR slag binder was very low. However, the 28-day compressive strength of the GKGB concrete manufactured by additionally mixing gypsum was developed up to a level similar to that of the OPC50+GGBFS50 (slag cement). On the other hand, the drying shrinkage of the GKGB concrete was $121.8 \% \sim 129.0 \%$ compared with that of slag cement.

2. The level of the hydration heat peak was very low in GKGB compared with OPC and OPC50+GGBFS50. And, the cumulative hydration heat of GKGB was $27.3 \% \sim 36.3 \%$ compared with that of OPC, which is very low and is expected to be useful for the reduction in the hydration heat of mass concrete in the future.

3. The cumulative porosity of the GKGB paste was evaluated as 2.4 to 2.6 times higher than that of OPC. In terms of pore size, there was almost no difference in the gel pores with the sizes of less than 10nm. But the number of capillary pores with the sizes of $10 \sim 100 \mathrm{~nm}$ and $100 \sim 10,000 \mathrm{~nm}$ was much greater compared with that of OPC. 
4. Through the XRD analysis results, main hydrates of OPC and OPC50+GGBFS50 were found as $\mathrm{Ca}(\mathrm{OH})_{2}, \mathrm{C}-$ $\mathrm{S}-\mathrm{H}, \mathrm{C}-\mathrm{A}-\mathrm{H}, 2 \mathrm{CaO} \cdot \mathrm{SiO}_{2}$ and $3 \mathrm{CaO} \cdot \mathrm{SiO}_{2}$, while main hydrates of $\mathrm{GKGB}$ was found as ettringite.

5. It was found that the shape of ettringite of OPC looked like a thin needle, while that of GKGB looked like a comparatively thick needle. The thick needle-shaped ettringite of GKGB formed a sort of a frame structure that could contribute the structural stability. But both porosity and absorption were high due to its loose structure, resulting in an increase in the drying shrinkage. Through the SEM image, it confirmed that high amounts of capillary pores formed out of thick needle-shaped ettringite in terms of GKGB.

Through a series of fundamental experiments, it was found that it is possible to make a cement-free binder consisting of the GGBFS, KR slag and gypsum. Based on the research findings, it is also planned to seek a reduction methods for the drying shrinkage of GKGB.

In addition, based on GKGB's unique features of high porosity and high absorption, its usability as a material for the sound absorption, sound insulation and thermal insulation will be also reviewed in the future.

The GKGB would bring about a value-added utilization of the byproduct from iron \& steel making process. It is also expected as an eco-friendly and more economical construction material that can contribute to reduction in $\mathrm{CO}_{2}$ in the cement industry.

\section{References}

[1] Worrell E, Price L, Martin N, Hendriks C, Meida LO. Carbon dioxide emissions from the global cement industry. Ann Rev Energy Environ 2001: 26-203.

[2] Alexander J. Moseson, Dana E. Moseson, Michel W. Barsoum. High volume limestone alkali-activated cement developed by design of experiment. Cem Concr Com 2012; 34(3): 328-336.

[3] Kwon EH, Ahn JC, Cho BS and Park DC. A study on development of recycled cement made from waste cementitious powder. Constr Build Mater, 2015; 83: 174-180.

[4] Phair JW. Green chemistry for sustainable cement production and use. Green Chem 2006;8(9):763-780.

[5] Liu Y, Zhu W, Yang EH. Alkali-activated ground granulated blast-furnace slag incorporating incinerator fly ash as a potential binder, Constr Build Mater 2016;112: 1005-1012.

[6] Purdon AO. The action of alkalis on blast-furnace slag. J Soc Chem Ind 1940;59:191-202.

[7] Özbay E, Erdemir M, Durmus HI. Utilization and efficiency of ground granulated blast furnace slag on concrete properties - A review, Constr Build Mater 2016;105: 423-434

[8] Jolicoeur C, Simard MA, Sharman J, Zamojska R, Dupuis M, Spiratos N, Douglas E, Malhotra VM.

Chemical activation of blast-furnace slag, An overview and systematic experimental investigation. Advances in Concrete Technology, Ministry of Supply and Services, 1992:471-502 [in Canada].

[9]. Li Y, Sun Y. Preliminary study on combined-alkali-slag paste materials. Cem Concr Res 2000;30(6):963-66. [10]. Fernandez-Jimenez A, Puertas F. Effect of activator mix on the hydration and strength behaviour of alkaliactivated slag cements. Adv Cem Res 2003;15(3):129-36.

[11] Moseson AJ, Moseson DE, Barsoum MW. High volume limestone alkali-activated cement developed by design of experiment. Cem Concr Com 2012;34(3): 328-336. 
[12] Provis JL, Myers RJ, White CE, Rose V, van Deventer JSJ. X-ray microtomography shows pore structure and tortuosity in alkali-activated binders. Cem Concr Res 2012;42(6): 855-864.

[13] Juenger M, Winnefeld F, Provis J, Ideker J. Advances in alternative cementitious binders, Cem Concr Res 2011;41: 1232-1243.

[14] Bakharev T. Geopolymeric materials prepared using Class F fly ash and elevated temperature curing, Cem Concr Res 2005;35:1224-1232.

[15] Somna K, Jaturapitakkul C, Kajitvichyanukul P, Chindaprasirt P. NaOH-activated ground fly ash geopolymer cured at ambient temperature, Fuel 2011;90(6): 2118-2124.

[16] Kim MS, Jun YB, Lee CH, Oh JE. Use of $\mathrm{CaO}$ as an activator for producing a price competitive noncement structural binder using ground granulated blast furnace slag, Cem Concr Res 2013;54: 208-214.

[17] Kuo WT, Hou TC. Engineering properties of alkali-activated binders by use of desulfurization slag and GGBFS, Constr Build Mater 2014;66: 229-234.

[18] Yang KH, Cho AR, Song JK, Nam SH. Hydration products and strength development of calcium hydroxide-based alkali-activated slag mortars, Constr Build Mater 2012;29: 410-419.

[19] Jeong Y, Oh JE, Jun YB, Park JN, Ha JH, Shon SG. Influence of four additional activators on hydratedlime $\left[\mathrm{Ca}(\mathrm{OH})_{2}\right]$ activated ground granulated blast-furnace slag, Cem Conc Com 2016;65: 1-10

[20] HFW Taylor, Cement chemistry (2nd edition), Thomas Telford 1997

[21] Ready-mixed concrete 2011[Korea standard F 4009]

[22] Testing method for length change of mortar and concrete 1995 [Korea standard F 2424]

[23] Winslow DN, Diamond S. A mercury porosimetry study of the evolution of porosity in cement, ASTM J Mater 1970;5(3):564-85.

[24] Ritter HL, Drake LC. Pore-size distribution in porous materials. Anal Chem 1948;20(7):665-70. 
Table 1. Materials used

\begin{tabular}{|c|c|}
\hline Materials & Properties \\
\hline Cement & $\begin{array}{l}\text { - Ordinary Portland Cement } \\
\text { - Density : } 3.15 \mathrm{~g} / \mathrm{cm}^{3} \\
\text { - Blaine fineness }: 3,410 \mathrm{~cm}^{2} / \mathrm{g}\end{array}$ \\
\hline GGBFS & $\begin{array}{l}\text { - Ground granulated blast furnace slag } \\
\text { - Density : } 2.98 \mathrm{~g} / \mathrm{cm}^{3} \\
\text { - Blaine fineness }: 4,330 \mathrm{~cm}^{2} / \mathrm{g}\end{array}$ \\
\hline KR slag & $\begin{array}{l}\text { - Kambara Reactor slag } \\
\text { - Density : } 3.01 \mathrm{~g} / \mathrm{cm}^{3} \\
\text { - Blaine fineness : } 4,040 \mathrm{~cm}^{2} / \mathrm{g} \\
\end{array}$ \\
\hline Gypsum & $\begin{array}{l}\text { - Anhydrous gypsum } \\
\text { - Density : } 2.93 \mathrm{~g} / \mathrm{cm}^{3} \\
\text { - Blaine fineness }: 4,530 \mathrm{~cm}^{2} / \mathrm{g}\end{array}$ \\
\hline Coarse aggregate & $\begin{array}{l}\text { - Crushed aggregate } \\
\text { - Max size }: 20 \mathrm{~mm} \\
\text { - Density }: 2.65 \mathrm{~g} / \mathrm{cm}^{3} \\
\text { - F.M. : } 6.13 \\
\text { - Absorption ratio : } 1.32\end{array}$ \\
\hline Fine aggregate & $\begin{array}{l}\text { - River sand } \\
\text { - Max size }: 5 \mathrm{~mm} \\
\text { - Density : } 2.54 \mathrm{~g} / \mathrm{cm}^{3} \\
\text { - F.M. : } 2.89 \\
\text { - Absorption ratio : } 1.03\end{array}$ \\
\hline High range water reducer & - Polycarboxylic acid type \\
\hline
\end{tabular}

Table 2. Chemical compositions and physical properties of the materials

\begin{tabular}{cccccccccc}
\hline \multirow{2}{*}{ Materials } & \multicolumn{8}{c}{ Chemical compositions (\%) } \\
\cline { 2 - 11 } & $\mathrm{CaO}$ & $\mathrm{SiO}_{2}$ & $\mathrm{Al}_{2} \mathrm{O}_{3}$ & $\mathrm{Fe}_{2} \mathrm{O}_{3}$ & $\mathrm{MgO}$ & $\mathrm{Na}_{2} \mathrm{O}$ & $\mathrm{K}_{2} \mathrm{O}$ & $\mathrm{SO}_{3}$ & $\mathrm{C}$ \\
\hline OPC & 62.20 & 20.70 & 6.20 & 3.10 & 2.80 & 0.10 & 0.84 & 2.10 & - \\
\hline GGBS & 43.51 & 32.75 & 15.61 & 0.50 & 4.41 & 0.25 & 0.49 & 0.04 & - \\
\hline KR slag & 62.21 & 10.64 & 1.21 & 11.07 & 1.52 & 0.10 & - & 5.20 & 4.08 \\
\hline Gypsum & 41.57 & 0.73 & 0.17 & 0.16 & - & 0.02 & 0.03 & 55.50 & - \\
\hline
\end{tabular}

Table 3. Mixture proportions of concrete

\begin{tabular}{|c|c|c|c|c|c|c|c|c|c|c|c|}
\hline \multirow[b]{2}{*}{ Specimens } & \multirow[b]{2}{*}{$\begin{array}{l}\text { Slump } \\
(\mathrm{mm})\end{array}$} & \multirow{2}{*}{$\begin{array}{c}\text { Air } \\
\text { Content } \\
(\%)\end{array}$} & \multirow[b]{2}{*}{$\begin{array}{l}\text { W/B } \\
(\%)\end{array}$} & \multirow[b]{2}{*}{$\begin{array}{l}\text { S/a } \\
(\%)\end{array}$} & \multicolumn{7}{|c|}{ Unit weight $\left(\mathrm{kg} / \mathrm{m}^{3}\right)$} \\
\hline & & & & & Water & GGBFS & $\begin{array}{l}\mathrm{KR} \\
\text { slag }\end{array}$ & Gypsum & OPC & $\begin{array}{l}\text { Coarse } \\
\text { aggregate }\end{array}$ & $\begin{array}{c}\text { Fine } \\
\text { aggregate }\end{array}$ \\
\hline OPC 100 & \multirow{5}{*}{$180 \pm 25$} & \multirow{5}{*}{$4.5 \pm 1.5$} & 48.5 & 48 & 165 & 0.0 & 0.0 & 0.0 & 340.2 & 943.3 & 831.5 \\
\hline $\begin{array}{l}\text { OPC50+ } \\
\text { GGBFS50 }\end{array}$ & & & 48.5 & 48 & 165 & 170.1 & 0.0 & 0.0 & 170.1 & 939.1 & 827.7 \\
\hline $\begin{array}{c}\text { GGBFS } \\
81+K R 10+A G 9\end{array}$ & & & 48.5 & 48 & 165 & 275.6 & 34.0 & 30.6 & 0.0 & 934.7 & 823.9 \\
\hline $\begin{array}{c}\text { GGBFS } \\
78+K R 10+A G 12\end{array}$ & & & 48.5 & 48 & 165 & 265.4 & 34.0 & 40.8 & 0.0 & 934.7 & 823.8 \\
\hline $\begin{array}{c}\text { GGBFS } \\
75+K R 10+A G 15\end{array}$ & & & 48.5 & 48 & 165 & 262.0 & 34.0 & 44.2 & 0.0 & 934.6 & 823.8 \\
\hline
\end{tabular}


Table.4 Slump and air content of fresh concrete

\begin{tabular}{ccc}
\hline specimens & Slump (\%) & Air (\%) \\
\hline OPC100 & 170 & 3.8 \\
\hline OPC50+GGBFS50 & 170 & 4.3 \\
\hline GGBFS75+KR10+AG15 & 165 & 3.9 \\
\hline GGBFS78+KR10+AG12 & 165 & 3.7 \\
\hline GGBFS81+KR10+AG9 & 170 & 4.1 \\
\hline
\end{tabular}

Table. 5 Pore size distributions with binder types

\begin{tabular}{ccccc}
\hline \multirow{2}{*}{ Specimens } & \multicolumn{4}{c}{ Distribution with pore size (\%) } \\
\cline { 2 - 5 } & $1 \sim 10$ & $10 \sim 100$ & $100 \sim 10000$ & Total \\
\hline OPC & 12.1 & 82.9 & 4.9 & 100 \\
\hline OPC50+GGBFS50 & 13.3 & 81.9 & 4.8 & 100 \\
\hline GGBFS75+KR10+AG15 & 10.4 & 70.7 & 19.0 & 100 \\
\hline GGBFS78+KR10+AG12 & 11.0 & 74.4 & 14.6 & 100 \\
\hline GGBFS81+KR10+AG9 & 9.8 & 69.0 & 21.2 & 100 \\
\hline
\end{tabular}




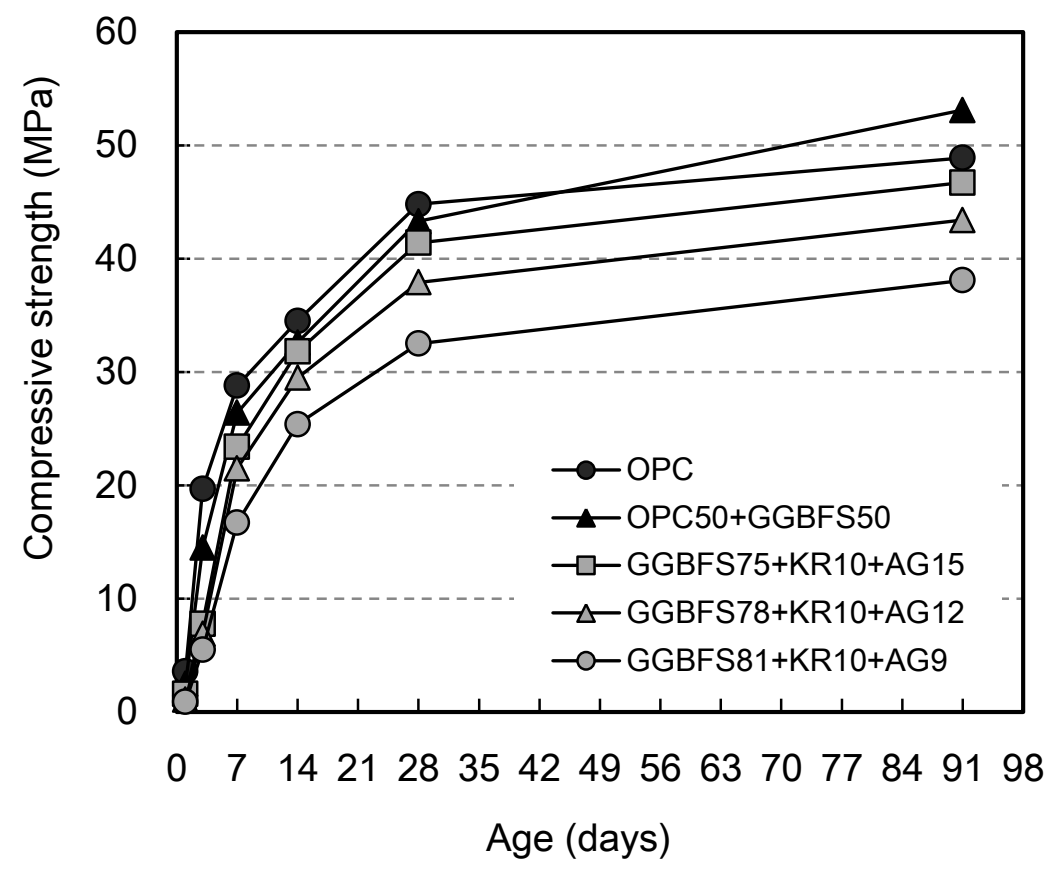

Figure.1 Compressive strength

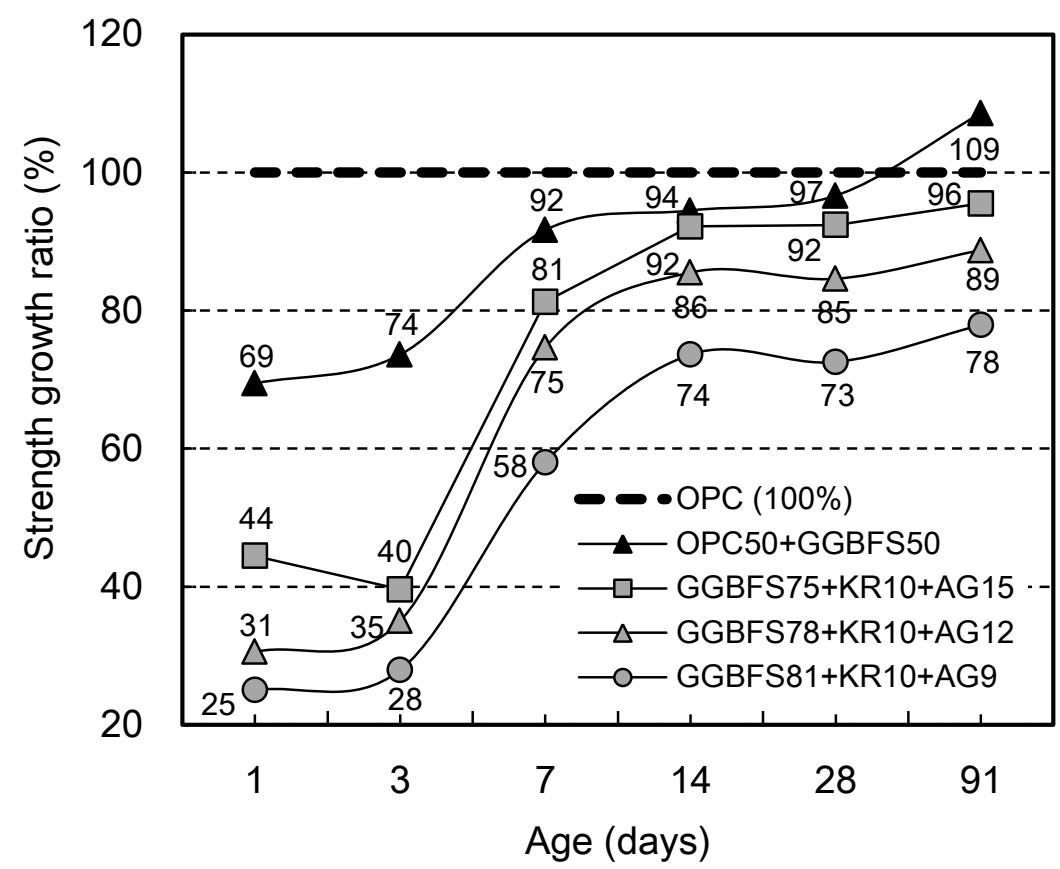

Figure.2 Compressive strength growth ratio 


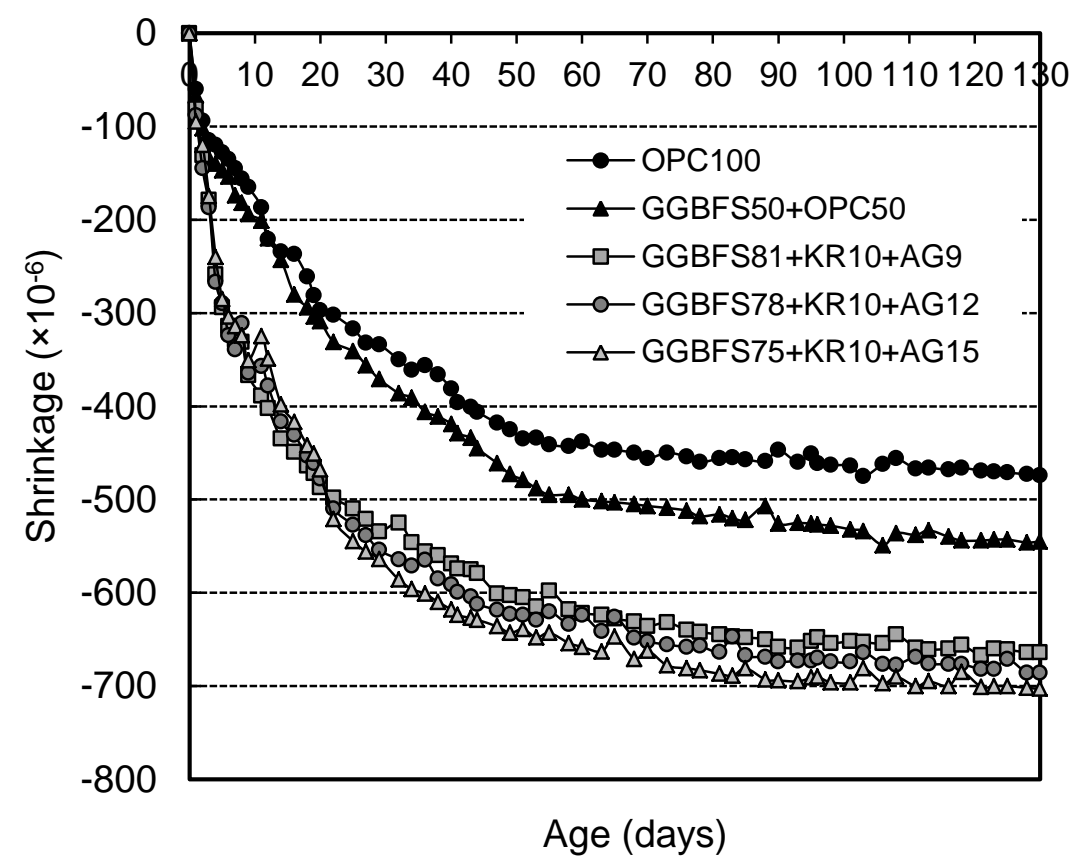

Figure.3 Drying shrinkage

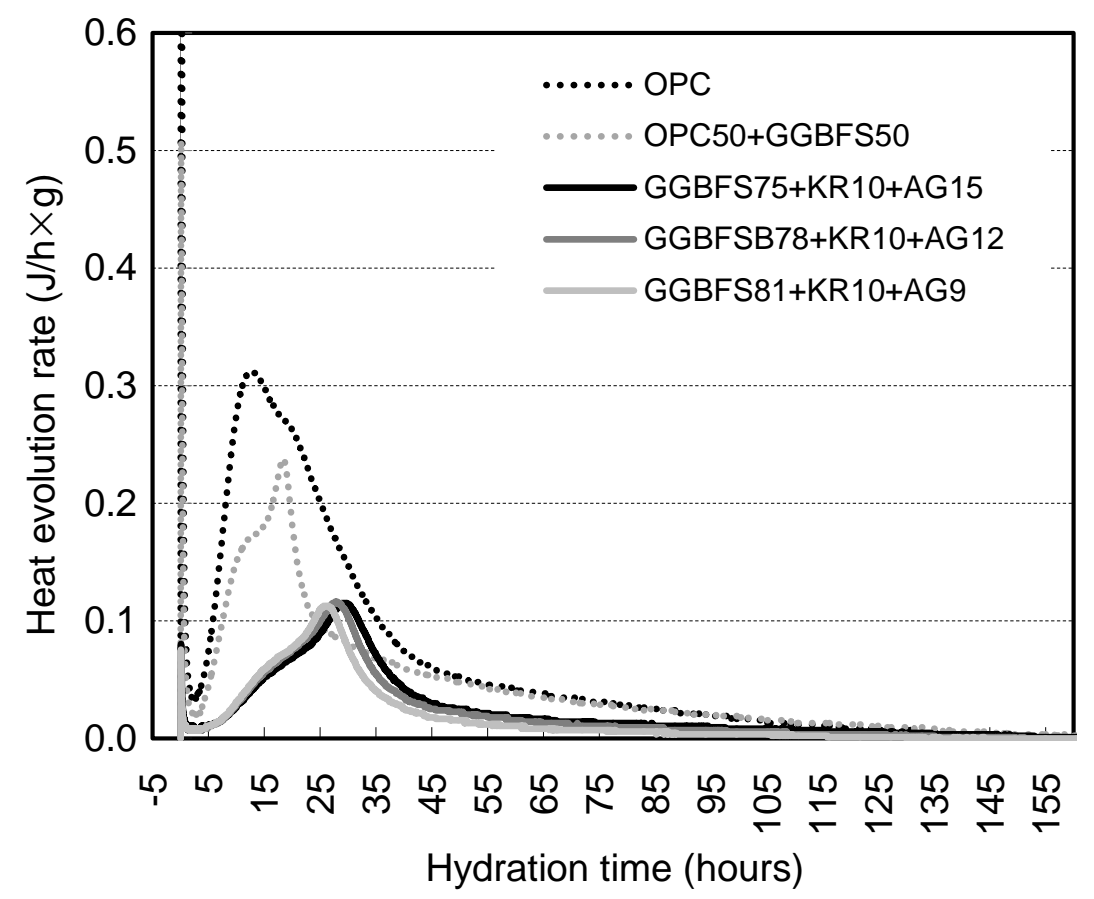

(a) Heat evolution 


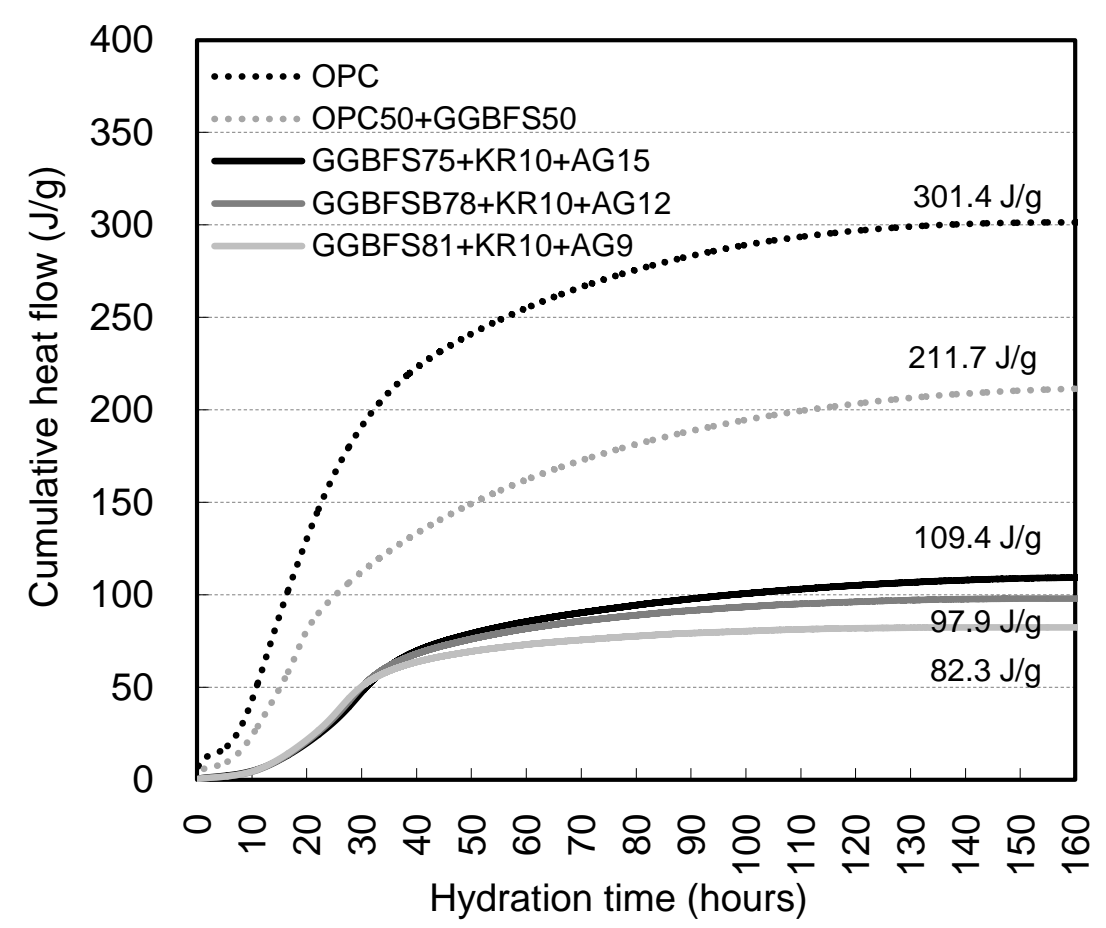

(b) Cumulative heat folw

Figure.4 Hydration heat

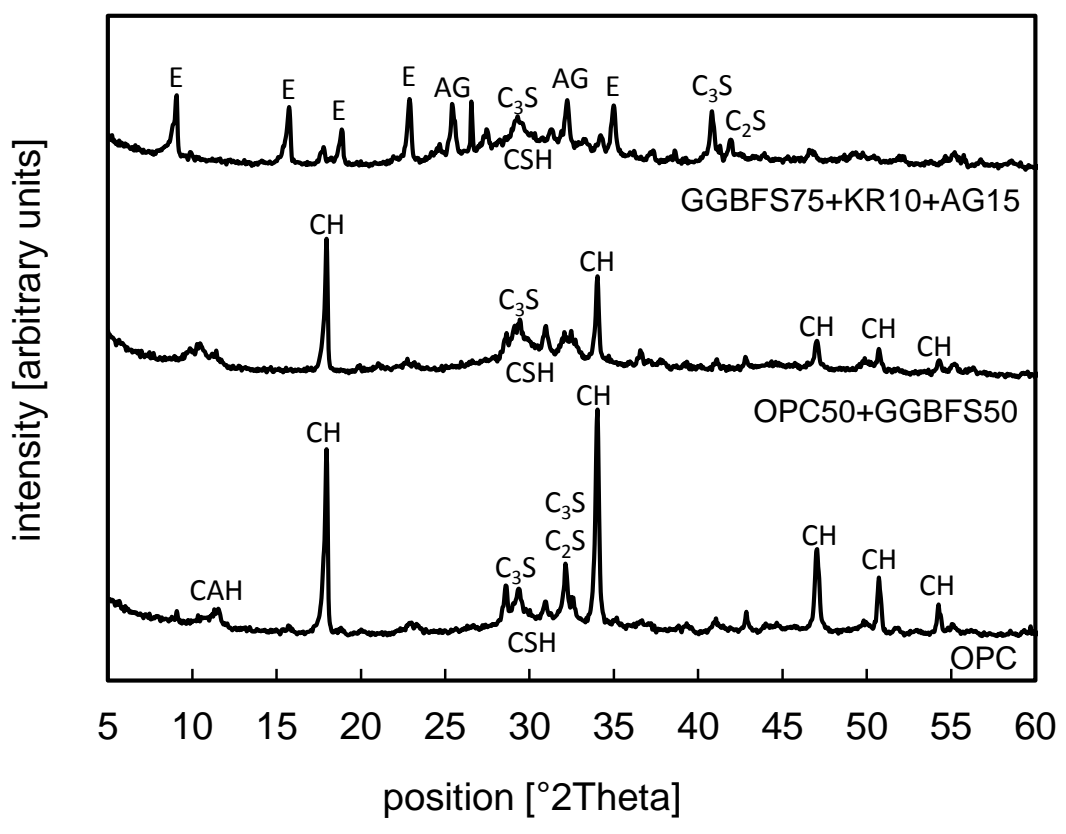

Figure.5 XRD spectra

( $\mathrm{CSH}$ : calcium silicate hydrates, $\mathrm{CAH}$ : calcium aluminum hydrates, $\mathrm{C}_{2} \mathrm{~S}: 2 \mathrm{CaO} \cdot \mathrm{SiO}, \mathrm{C}_{3} \mathrm{~S}: 3 \mathrm{CaO} \cdot \mathrm{SiO}_{2}, \mathrm{E}$ : $\left.3 \mathrm{CaO} \cdot \mathrm{Al}_{2} \mathrm{O}_{3} \cdot 3 \mathrm{CaSO}_{4} \cdot 32 \mathrm{H}_{2} \mathrm{O}, \mathrm{CH}: \mathrm{Ca}(\mathrm{OH})_{2}\right)$ 


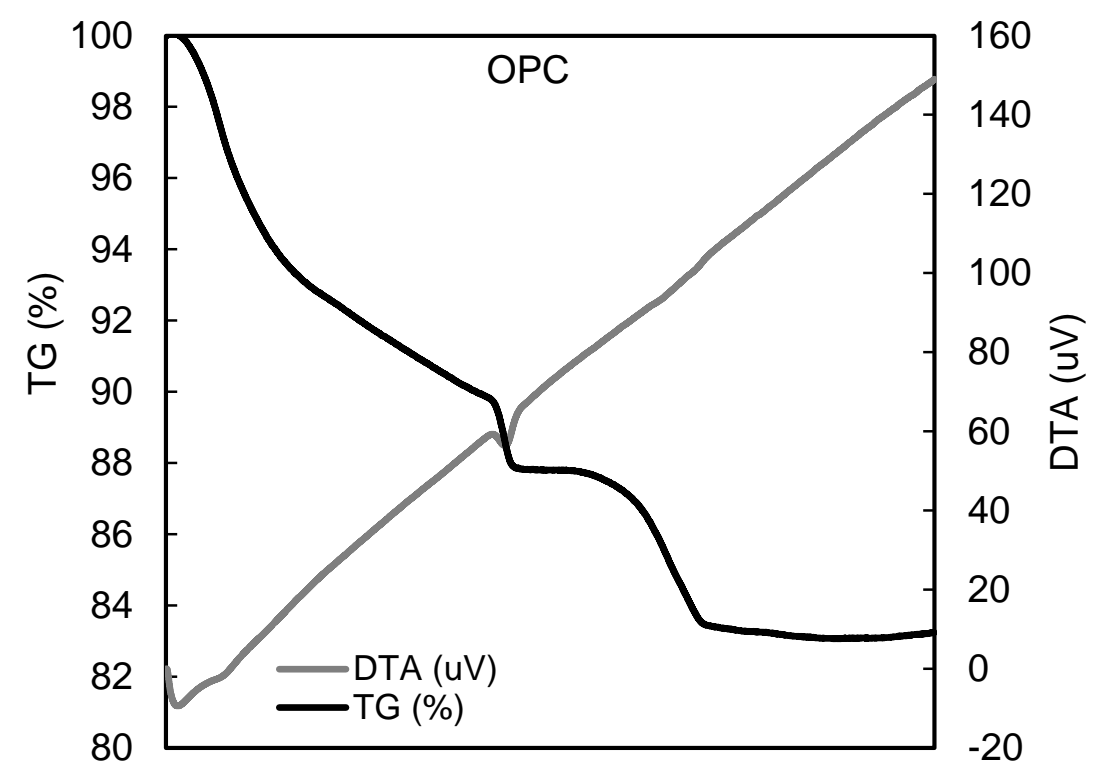

(a) OPC

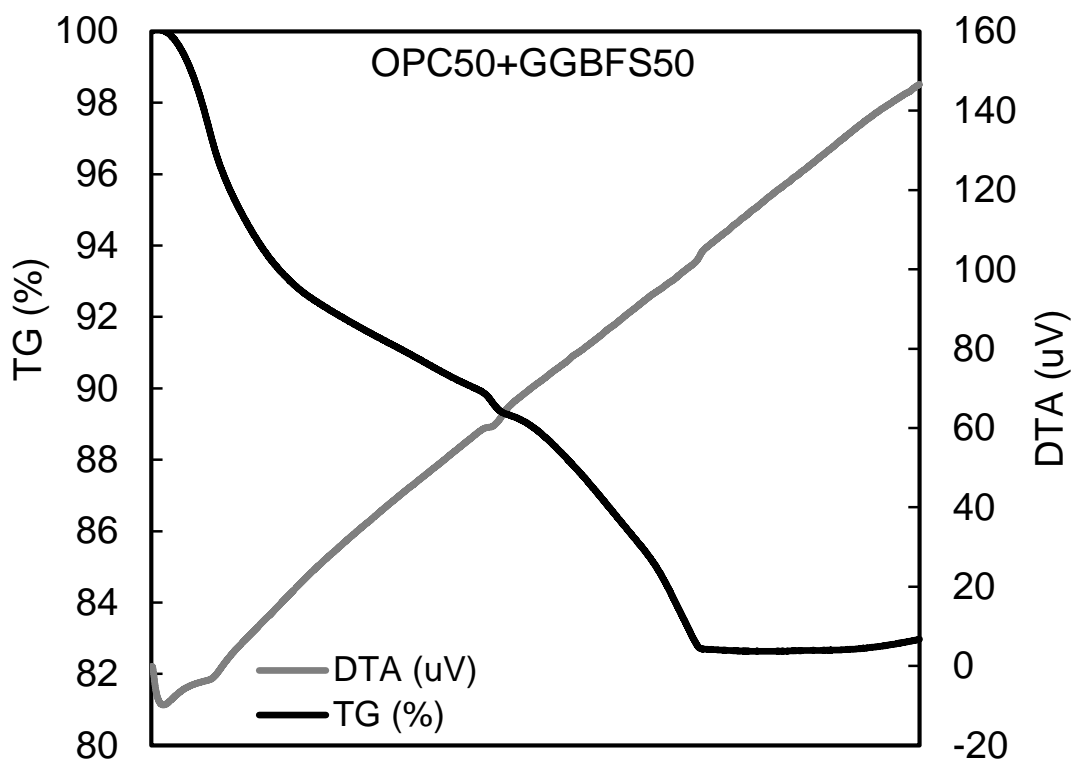

(b) OPC50+GGBFS50 


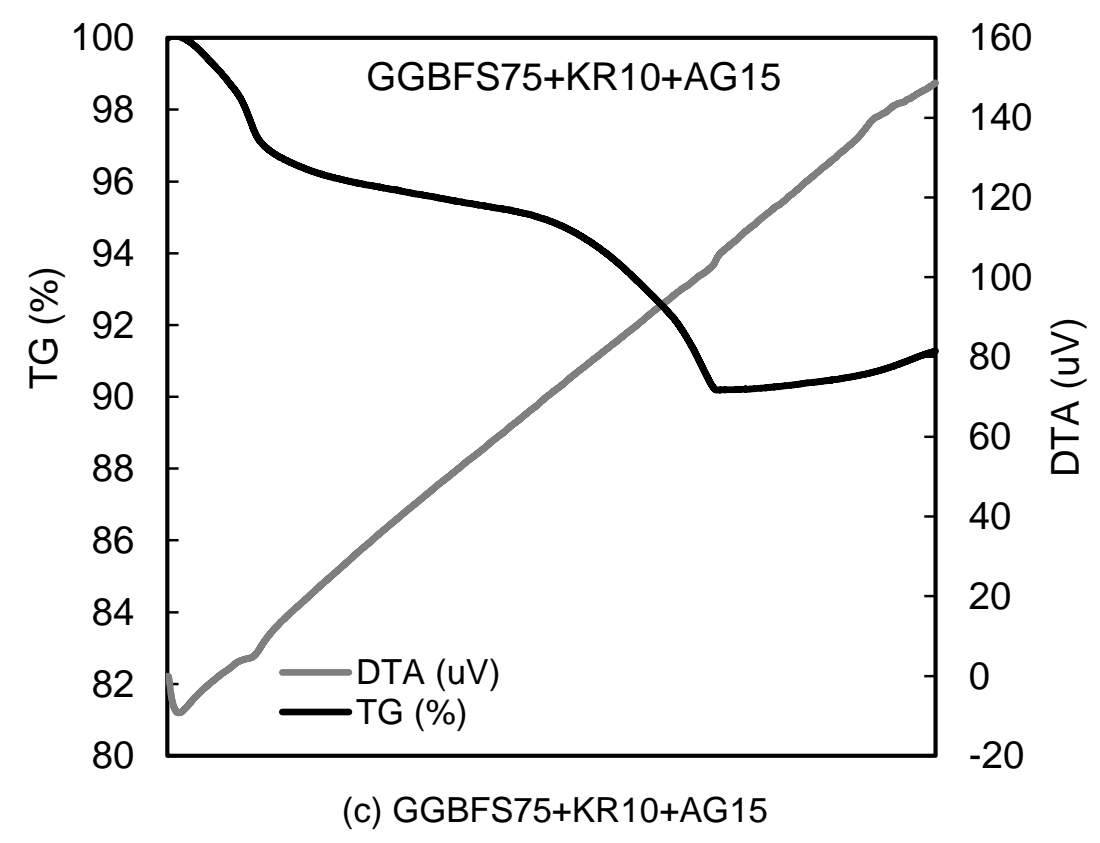

Fig.6 TG/DTA curves 


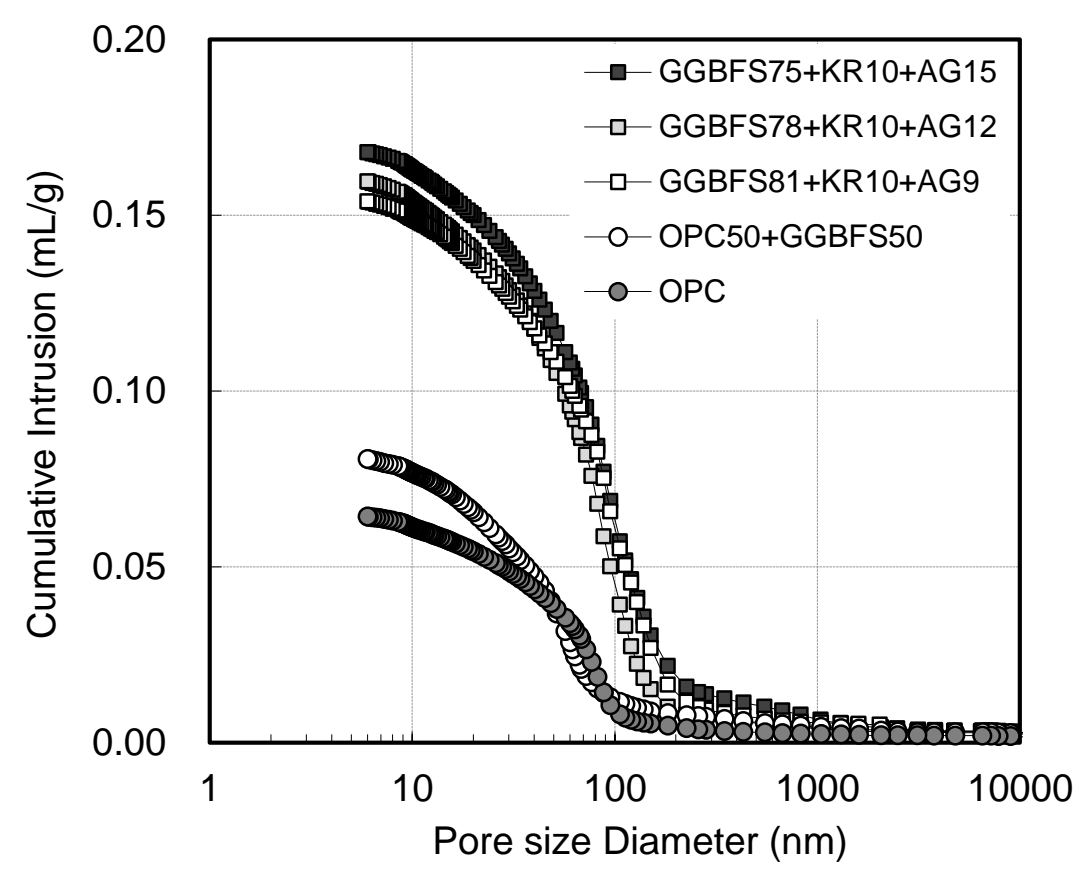

(a) Cumulative pore volume

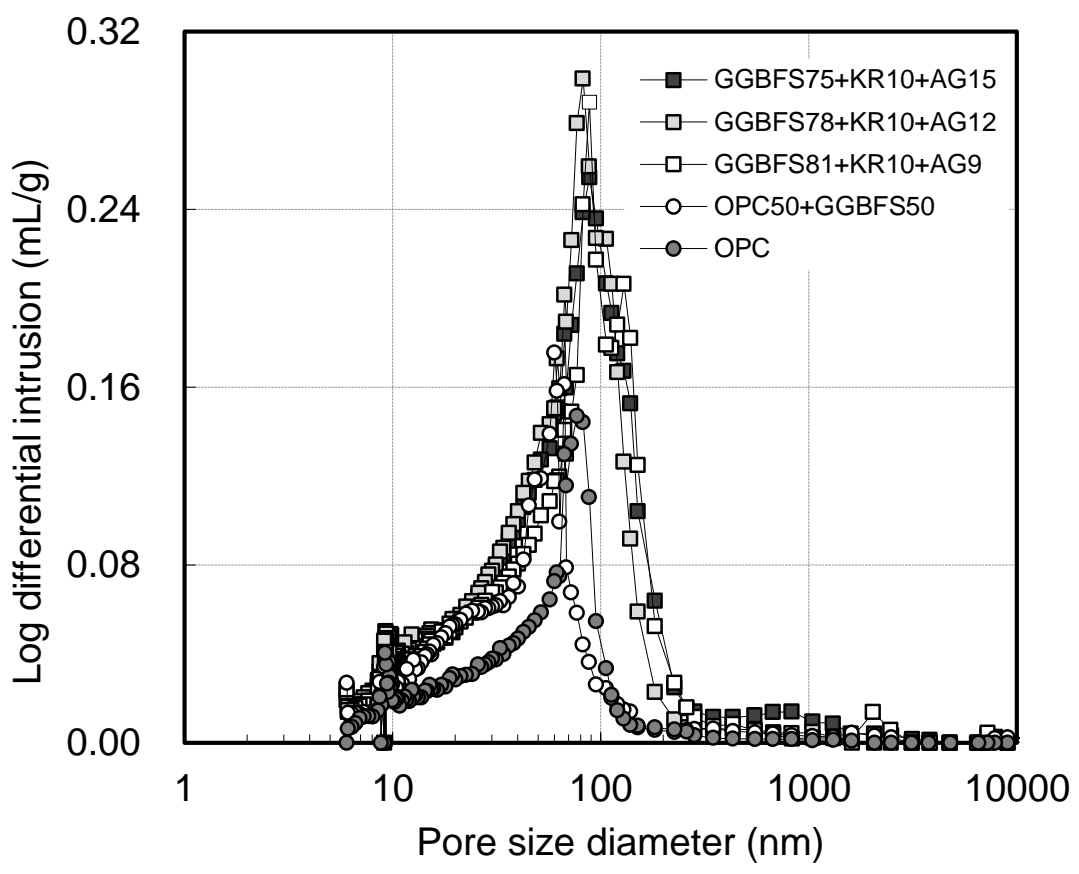

(b) Distribution of pore volume 


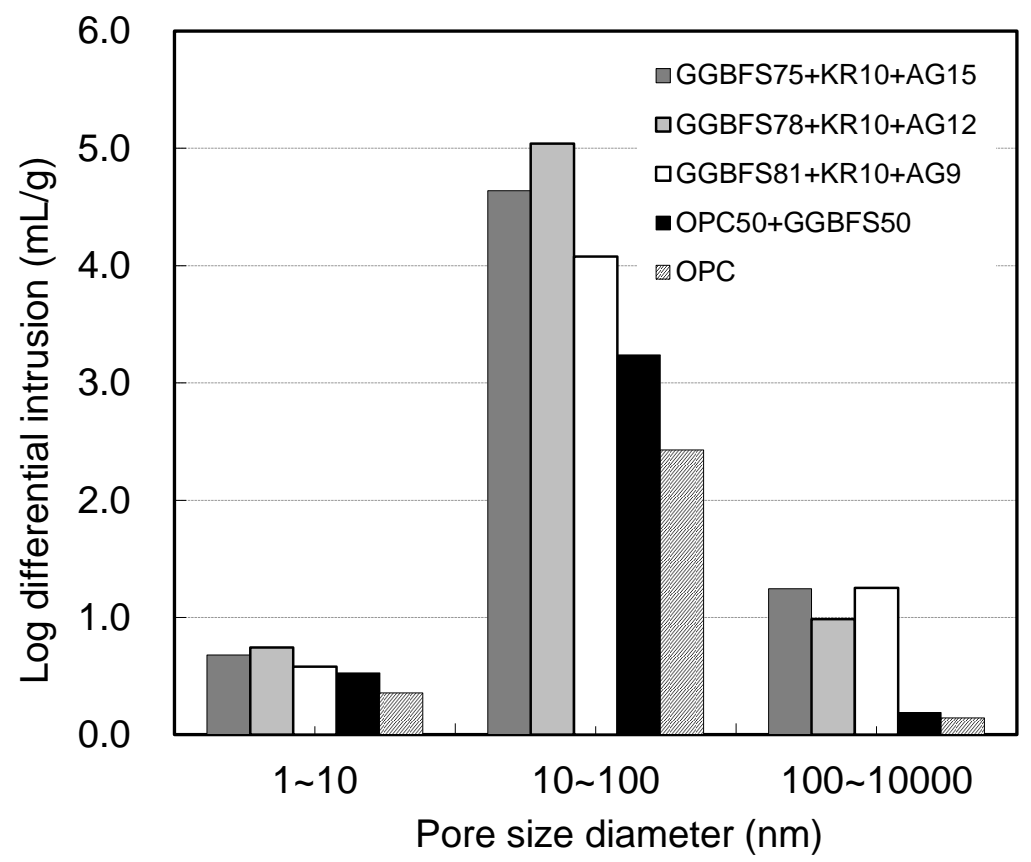

(c) Distribution with pore size

Figure. 7 Porosity of paste with binder types

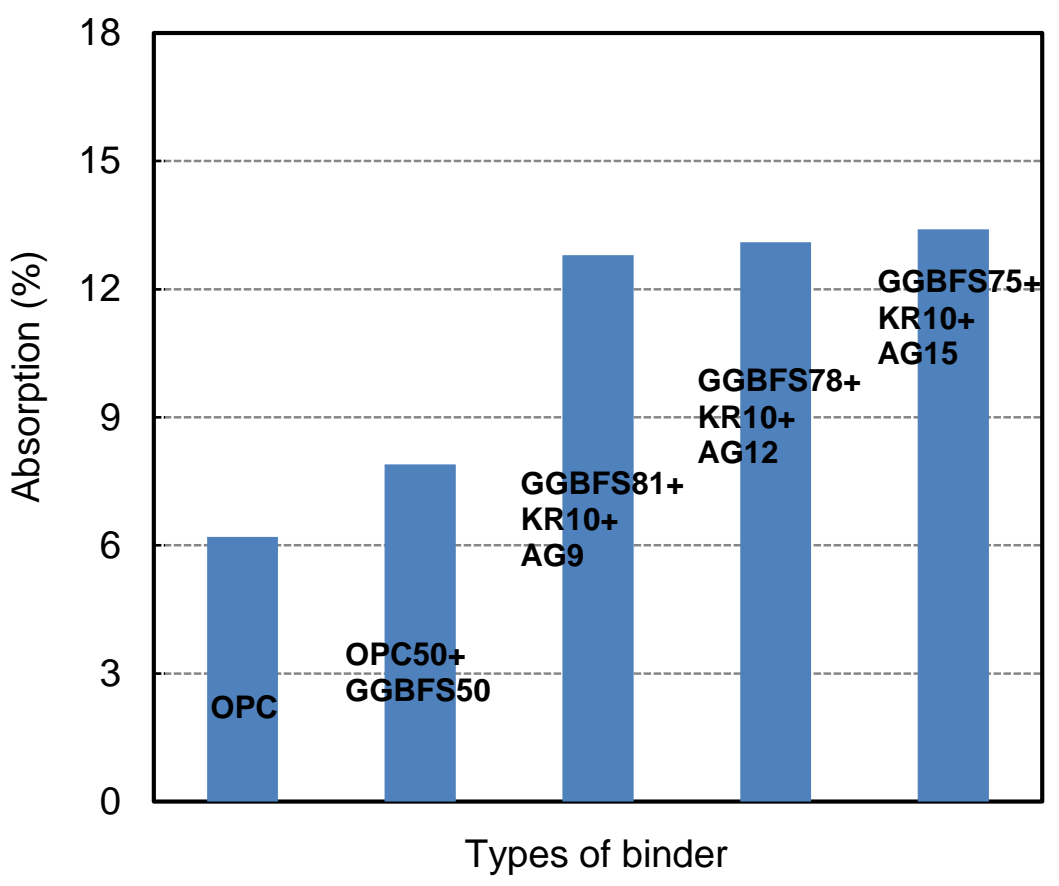

Figure. 8 Absorption 


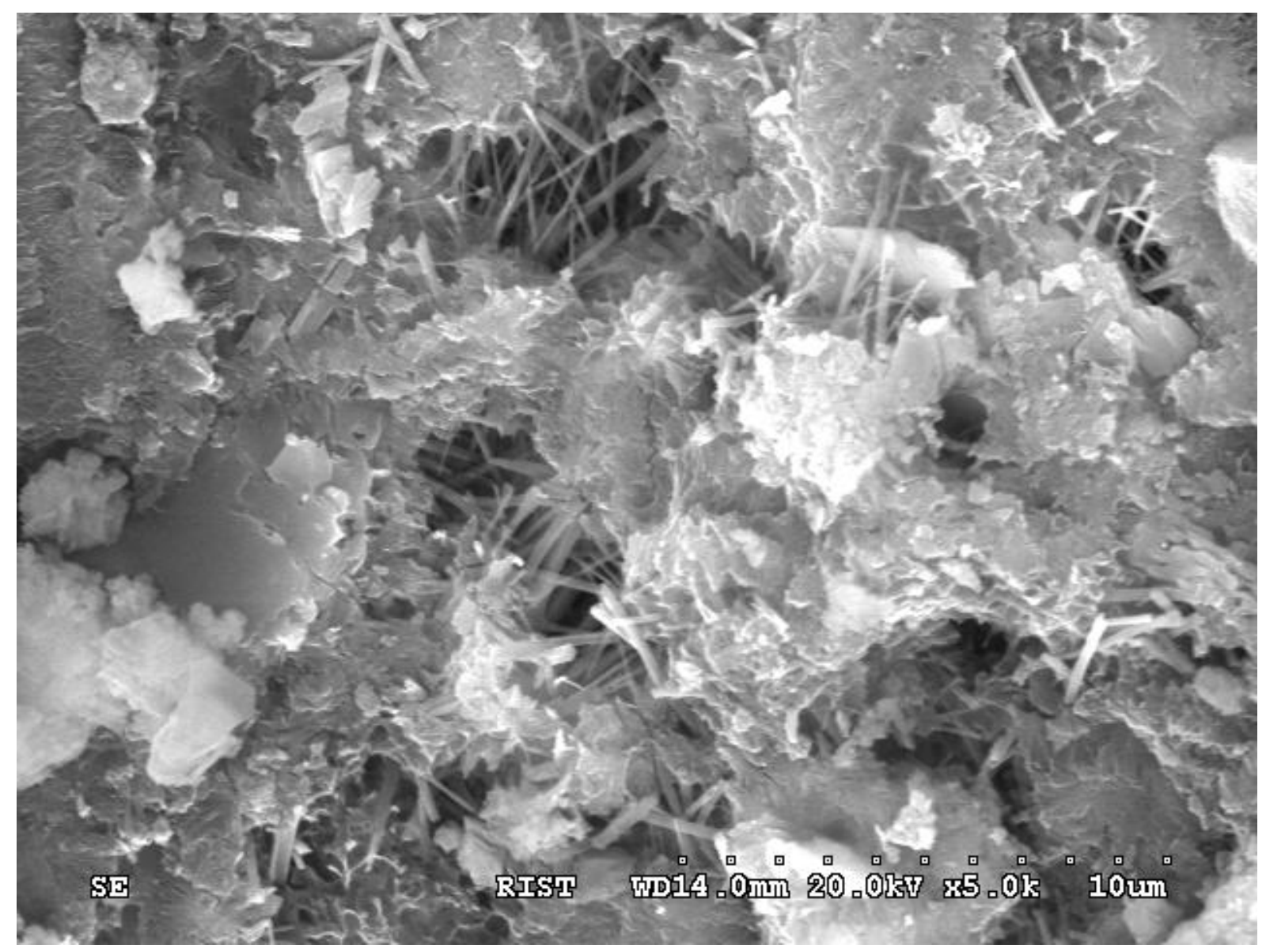

(a) OPC (7d.) 


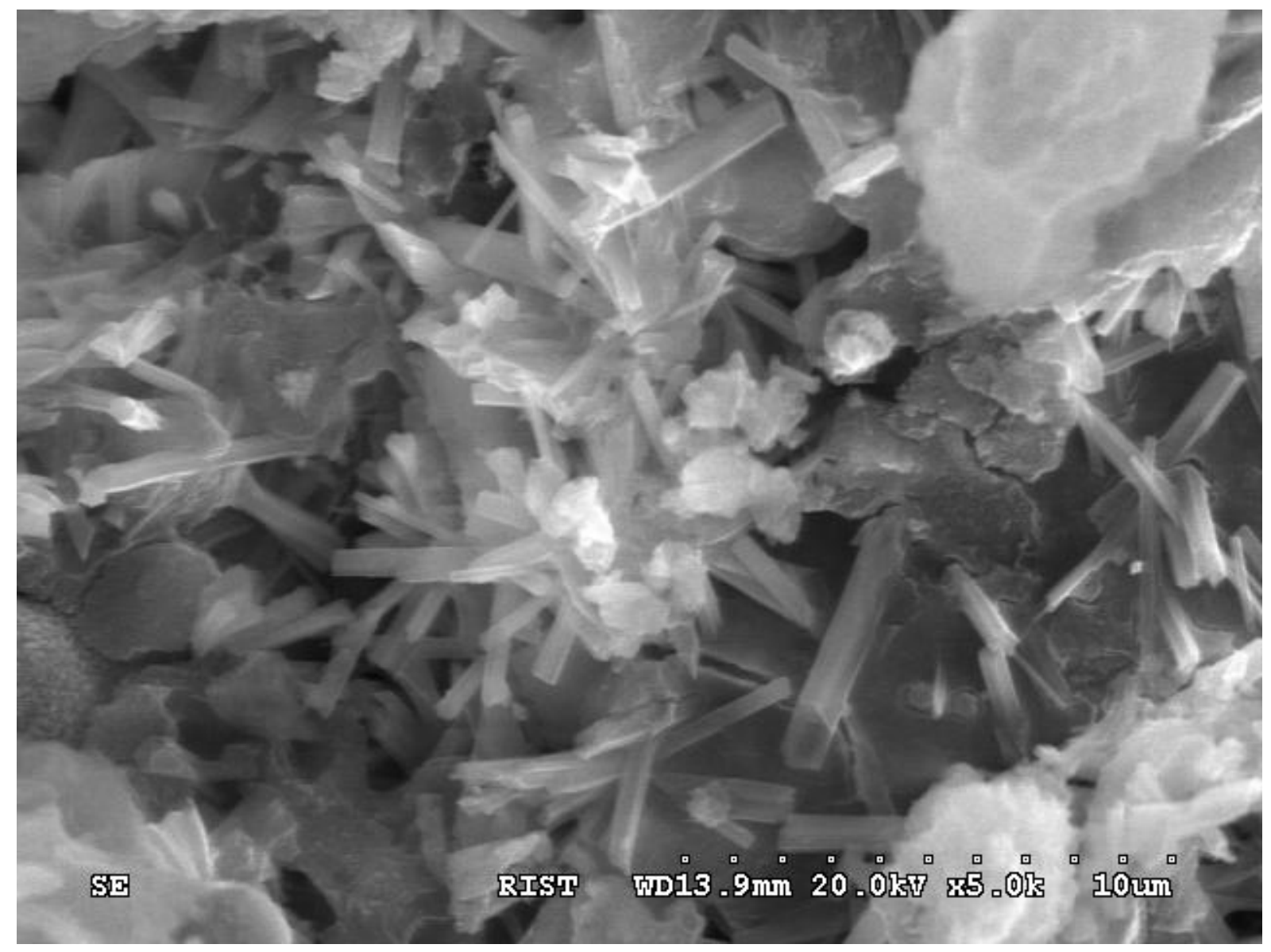

(b) GGBFS75\%+KR10\%+AG15\% (7d.) 


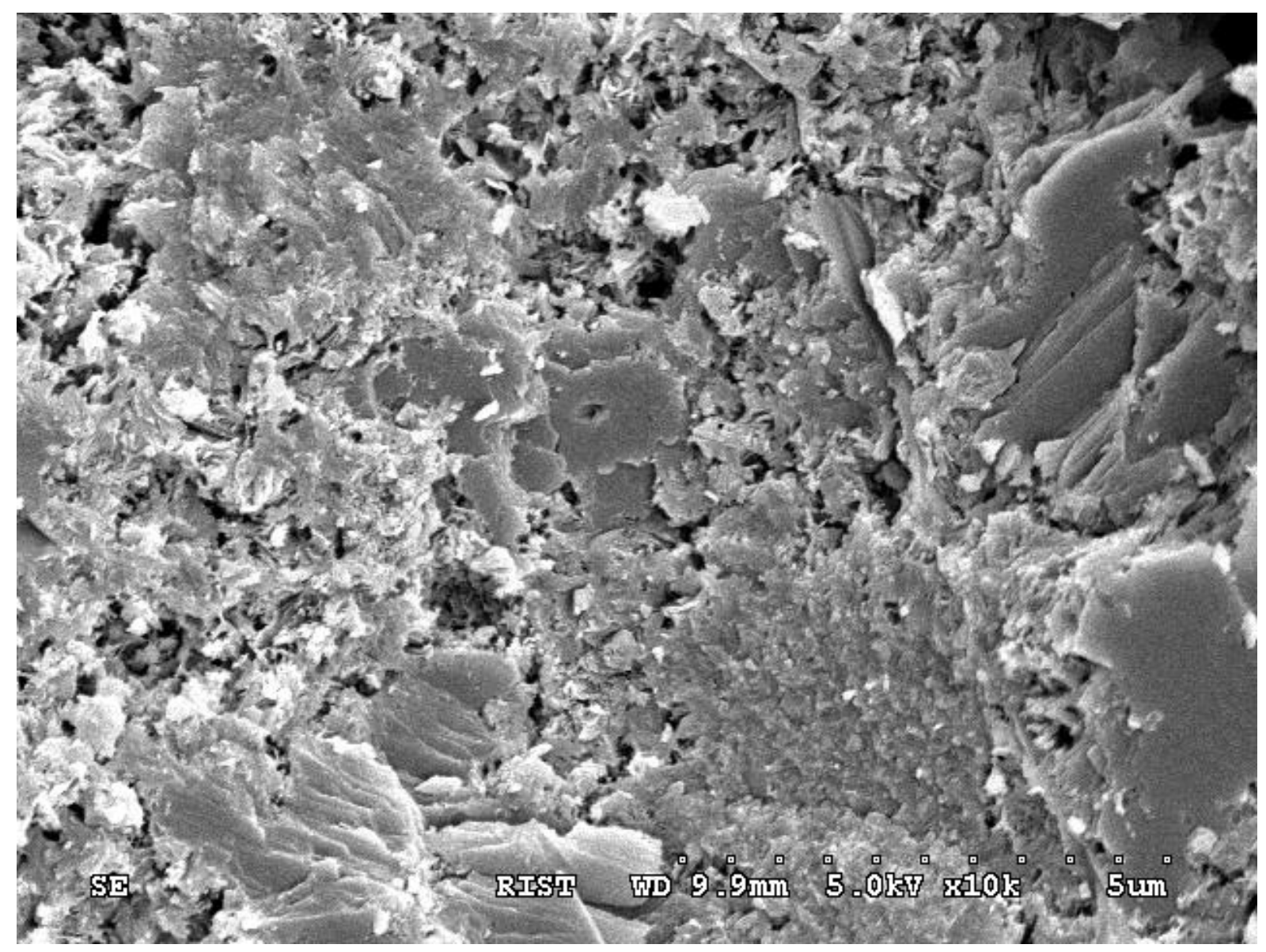

(c) OPC (91d.) 


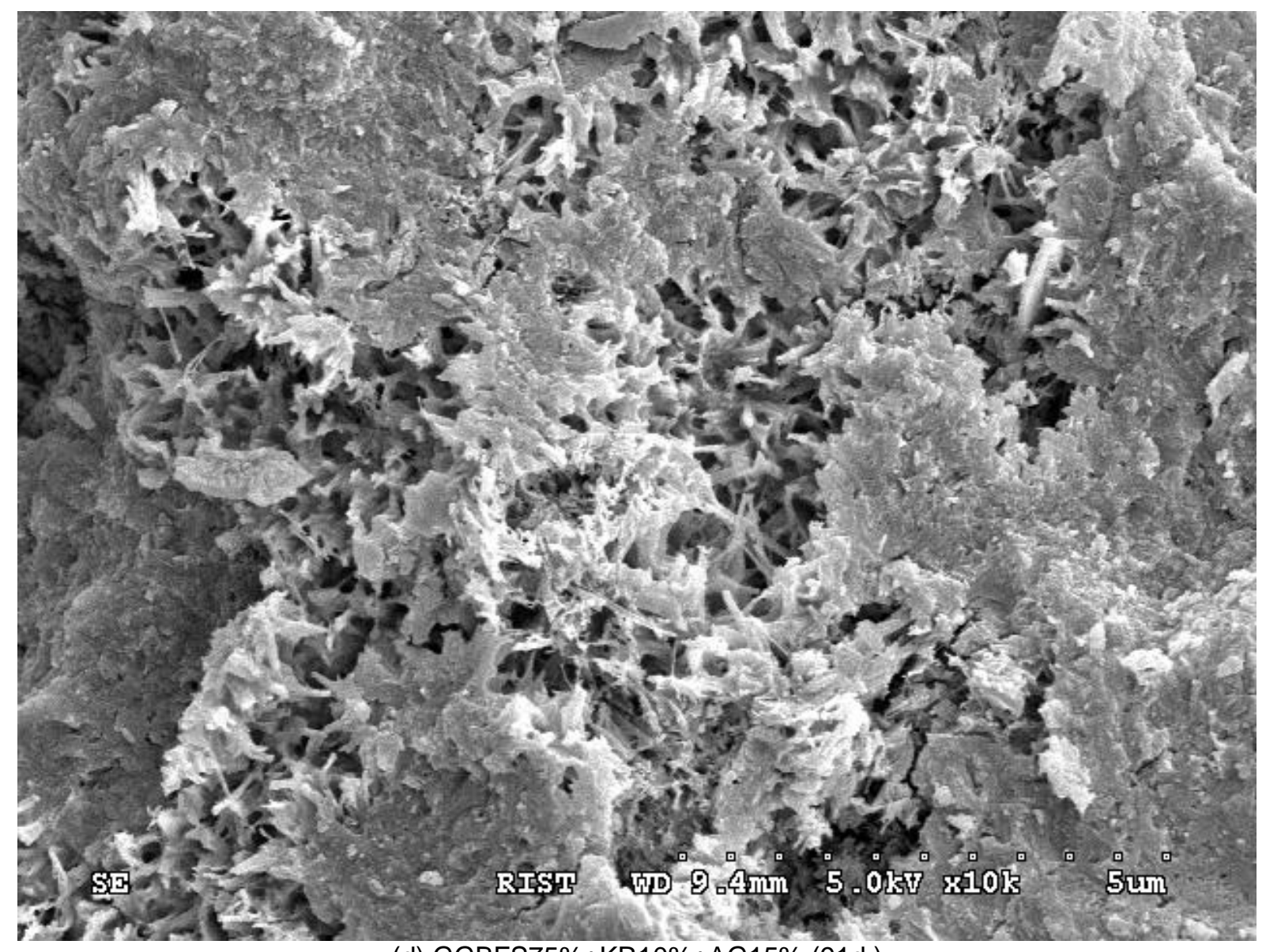

(d) GGBFS75\%+KR10\%+AG15\% (91d.)

Figure.9 SEM image 